\title{
Expression of estrogen receptor $-\alpha$ and $-\beta$ mRNAs in the male reproductive system of the rat as revealed by in situ hybridization
}

\section{N Mowa and T Iwanaga}

Laboratory of Anatomy, Graduate School of Veterinary Medicine, Hokkaido University, Kita-ku, Sapporo 060-0818, Japan

(Requests for offprints should be addressed to C N Mowa, Laboratory of Anatomy, Graduate School of Veterinary Medicine, Hokkaido University, Kita 18-Nishi 9, Kita-ku, Sapporo 060-0818, Japan;

Email: Chishimba@1ycos.com)

\begin{abstract}
We mapped the cellular expression of estrogen receptor (ER) $\alpha$ and $\operatorname{ER} \beta$ mRNAs in the male reproductive system of the rat during development and adulthood by in situ hybridization. The expression patterns of ER $\alpha \mathrm{mRNA}$ in the gonad, efferent duct and initial segment of the epididymis during the perinatal period were essentially similar to those of the adult: $\mathrm{ER} \alpha \mathrm{mRNA}$ signals were expressed most intensely in the epithelia of the efferent ducts and initial segment of the epididymis, and in the interstitial cells of the testis from the prenatal period to adulthood. However, ER $\alpha$ mRNA signals in the primordial epididymis and vas deferens during the prenatal period were confined to the outermost cellular layer of the ducts, whereas thereafter they were only expressed weakly in the
\end{abstract}

epithelium and stroma of the epididymis and moderately in the muscle layer of the vas deferens. ER $\beta$ signals were expressed intensely (1) in primordial germ and Sertoli cells only during the prenatal period, (2) in arterial walls in the adult testis, and (3) in the epithelium of the sex accessory glands from the perinatal period to adulthood. This report is the first to describe the cellular distribution of ER mRNA in the male reproductive organs during the perinatal period, and complements and confirms earlier data on its distribution in the adult. The broad expression of ERs in male reproductive organs suggests roles for estrogen in regulating tissue development and reproductive events.

Fournal of Molecular Endocrinology (2001) 26, 165-174

\section{INTRODUCTION}

One of the primary roles of estrogen is to induce the growth and function of reproductive and neuronal cells that are related to sexual development and behavior (Galand et al. 1971). Produced mainly in the ovary and adrenal gland in the female, estrogen exerts a strong influence over reproductive events (Freeman 1988). Although the presence of estrogen in the male gonad has been well documented for more than 50 years (see review by Carreau et al. 1999), it is only recently that studies on the exact role of estrogen in male reproduction and fertility have been undertaken (Meistrich et al. 1975, Couse \& Korach 1999, Hess 2000, Lee et al. 2000). Aromatase, a microsomal enzymatic complex which irreversibly converts androgens into estrogen, has been demonstrated in testicular cells including
Sertoli and Leydig cells and, more recently, in germ cells (Janulis et al. 1998, Carreau et al. 1999). Even though the overall production of estrogen by the testis, which is the major source of estrogen in the male, is much less than that produced by the ovaries, the concentration of estrogen in the rete testis and caput epididymis fluids has been reported to be higher than serum estradiol in the female (Hess et al. 1997b). Consequently, the influence of estrogen on male sexuality is expected to be profound (vom Saal 1980, Byskov \& Hoyer 1988).

Estrogenic effects on target tissues are principally mediated by estrogen receptors $\alpha(\mathrm{ER} \alpha)$ and $\beta$ $(\mathrm{ER} \beta)$, members of the steroid/thyroid hormone receptor superfamily, which regulate gene transcription through estrogen-responsive elements (Koike et al. 1987, Kuiper et al. 1996). Investigators have demonstrated the presence of ER using 
different techniques including steroid autoradiography and immunohistochemistry in the testis and reproductive tract of rodents during development and adulthood (Cooke et al. 1991, Greco et al. 1992, Hess et al. 1997a,b, Fisher et al. 1998, Saunders et al. 1998, Jefferson et al. 2000, Pelletier et al. 2000). In situ hybridization, immunohistochemistry and reverse transcriptase-polymerase chain reaction (RT-PCR) using tissues and cultured cells of adult rat testes have demonstrated predominant expression of ER $\alpha$ in the Leydig cells, while ER $\beta$ expression has been localized to the Sertoli and germ cells (Zhai et al. 1996, Fisher et al. 1997, Saunders 1998, Saunders et al. 1998, Pelletier et al. 2000). In tissues other than the testis, the most intense signals of ER $\alpha$ mRNA in the adult rodents were found in the epithelia of the efferent duct and initial segment of the epidydimis, sites responsible for semen concentration (Hess et al. 1997b, Fisher et al. 1998). ER $\alpha$ mRNA expression is also intense in the muscle layer of the vas deferens in the rat, while $\operatorname{ER} \beta$ mRNA is weakly expressed in the efferent duct, epidydimis, and vas deferens (Hess et al. 1997a). Although significant data on the cellular distribution of $\mathrm{ER} \mathrm{mRNA}$ in the male reproductive system have been generated, our current knowledge of its cellular expression during development and adulthood is still far from complete and, in some tissues, the data are inconsistent. The most obvious is the absence of data on the cellular expression of $\mathrm{ER} \alpha$ and $\operatorname{ER} \beta$ mRNAs in the male reproductive system during the prenatal period.

A thorough knowledge of the cellular distribution of ER in tissues is essential to identify which of the many heterogenous cell types respond to estrogen; subsequently, this knowledge provides a foundation for understanding the role of estrogen in male reproduction. Thus, this study was designed to map, systematically and in detail, the cellular distribution of $\mathrm{ER} \alpha$ and $\mathrm{ER} \beta$ mRNAs in the whole reproductive system of the male rat, from the prenatal period through adulthood, using in situ hybridization. The data on ER mRNA expression of the penis have been submitted for publication elsewhere. Our findings confirm and extend the data of earlier reports on ER mRNA distribution in the male reproductive system.

\section{MATERIALS AND METHODS}

\section{Animals}

Normal immature and adult Wistar male rats, from fetal day 14 to 90 days after birth, were killed for histological procedures as described below. The older rats were anesthetized by intraperitoneal injection with pentobarbital sodium solution (Nembutal, Abbot, Chicago, IL, USA), $0 \cdot 5 \mathrm{ml} / \mathrm{kg}$ body weight, whereas the neonates were anaesthetized with ether vapor. The animals were treated in accordance with the Guidelines on the Handling and Training of Laboratory Animals published by the Universities Federation for Animal Welfare, $\mathrm{UK}$.

\section{Probes}

Proven ER $\alpha$ and ER $\beta$ probes, complementary to 301-346 base pairs of ER $\alpha$ cDNA (Koike et al. 1987 ) and 45-90 base pairs of ER $\beta$ cDNA (Kuiper et al. 1996) respectively, were utilized in this study (Mowa \& Iwanaga 2000). The oligonucleotides were labeled with ${ }^{35} \mathrm{~S}-\mathrm{dATP}$, using terminal deoxyribonucleotidyl transferase (Promega, Madison, WI, USA) at a specific activity of $0.5 \times 10^{9}$ d.p.m./ $\mu \mathrm{g}$ DNA.

\section{In situ hybridization}

The in situ hybridization procedure was performed as previously described (Mowa \& Iwanaga 2000). Briefly, $20 \mu \mathrm{m}$ cryostat sections were mounted on glass slides, fixed in 4\% paraformaldehyde and then acetylated with $0.25 \%$ acetic anhydride in $0.1 \mathrm{M}$ triethanolamine- $\mathrm{HCl}(\mathrm{pH} 8 \cdot 0)$.

The prepared sections were prehybridized for $2 \mathrm{~h}$ in a buffer containing $50 \%$ formamide, $0 \cdot 1 \mathrm{M}$ Tris- $\mathrm{HCl}(7 \cdot 5), 4 \times \mathrm{SSC}(1 \times \mathrm{SSC}=150 \mathrm{mM} \mathrm{NaCl}$ and $15 \mathrm{mM}$ sodium citrate), 0.02\% Ficoll, 0.02\% polyvinylpyrrolidone, $0.02 \%$ bovine serum albumin, $0.6 \mathrm{M} \mathrm{NaCl}, 0.25 \%$ sodium dodecyl sulfate (SDS), $200 \mu \mathrm{g} / \mathrm{ml}$ tRNA, $1 \mathrm{mM}$ EDTA and $10 \%$ dextran sodium sulfate. Hybridization was performed at $42{ }^{\circ} \mathrm{C}$ for $10 \mathrm{~h}$. The slides were washed in $2 \times \mathrm{SSC}$ containing $0.1 \%$ sarkosyl (Nacalai Tesque, Kyoto, Japan) and twice at $55^{\circ} \mathrm{C}$ in $0 \cdot 1 \times$ SSC containing $0 \cdot 1 \%$ sarkosyl. The sections were exposed to Hyperfilm- $\beta$ max (Amersham International, Amersham, Bucks, UK), dipped in Kodak NTB2 nuclear track emulsion and exposed.

The specificity of the in situ hybridization was confirmed by the disappearance of signals when an excess dose of corresponding cold oligonucleotides was added to the hybridization fluid. Consistent ER mRNA signals above background levels were considered positive and scored as strong, moderate or weak. 

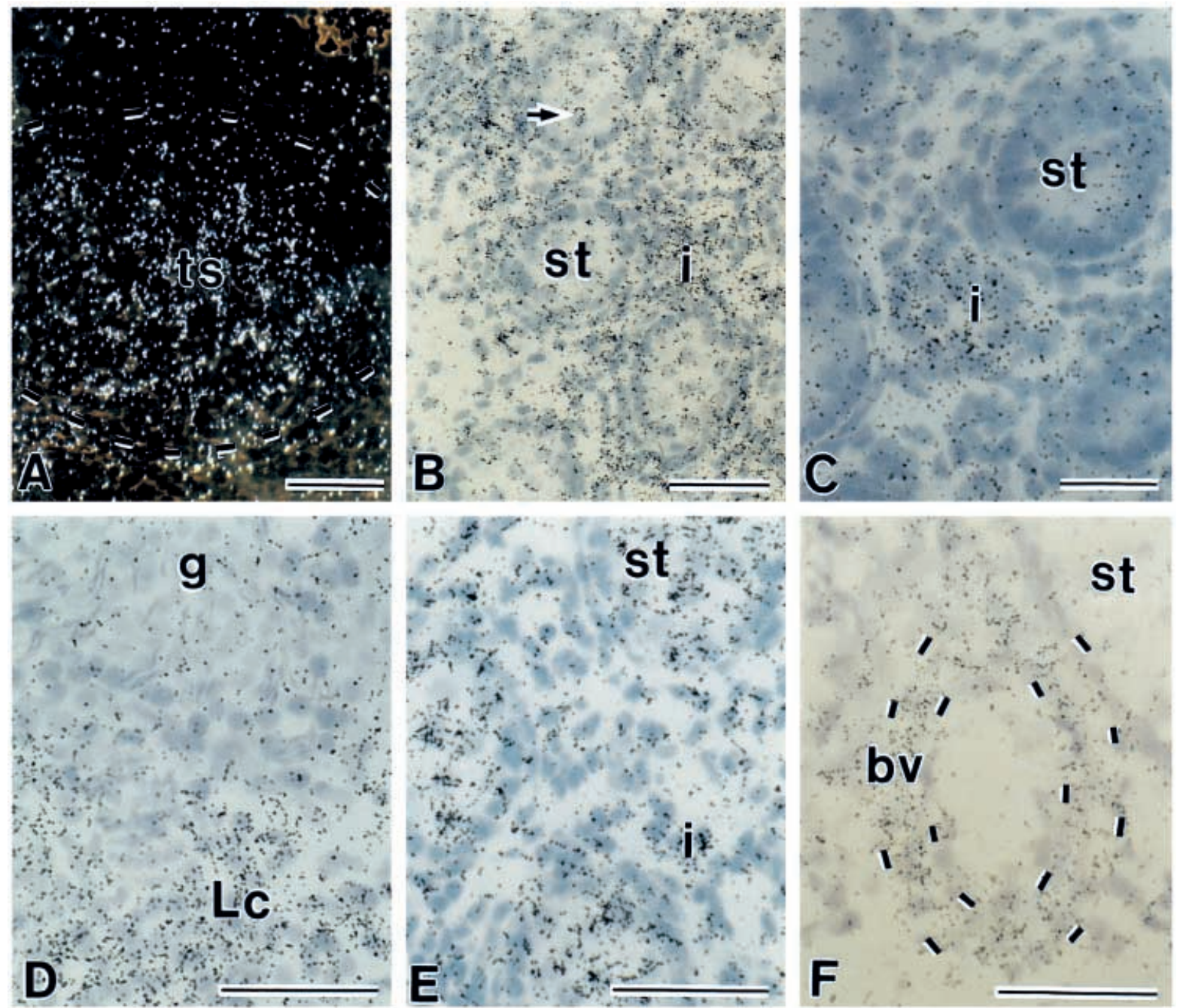

FIgURE 1. Distribution of $\mathrm{ER} \alpha$ and $\mathrm{ER} \beta$ mRNAs in the rat testis. (A) Initial signals for $\mathrm{ER} \alpha \mathrm{mRNA}$ in the testis (ts) are found at fetal day 14, as shown by the dark-field image. (B-D) At fetal day 17 (B) and postnatal day 14 (C), ER $\alpha$ mRNA signals are essentially confined to the interstitial cells (i), with weak and scattered signals in the germ cells (arrow) (st, seminiferous tubule). The signals are also restricted to the interstitial cells in the adult (D) (g, germ cells; Lc, Leydig cells). (E) Signals of ER $\beta$ mRNA are found largely within the seminiferous tubule (st) at fetal day 17 (i, interstitial cells). (F) In adults, ER $\beta$ mRNA signals are localized to the testicular blood vessels (bv), with very weak signals in the seminiferous tubules $(\mathrm{st})$. Bar $=100 \mu \mathrm{m}(\mathrm{A}-\mathrm{C})$, $200 \mu \mathrm{m}(\mathrm{D}-\mathrm{F})$.

\section{RESULTS}

\section{Testis}

Initial signals of ER $\alpha$ mRNA in the primordial gonad were diffusely expressed in the mesenchyme by fetal day 14 (Fig. 1A). By fetal day 17 its signals aggregated largely to the interstitial cells, identified as precursor Leydig cells (Fig. 1B). Scattered round cells within the developing seminiferous tubules, presumed to be gonocytes, expressed detectable signals for $\mathrm{ER} \alpha \mathrm{mRNA}$ from the late prenatal to the late neonatal periods (Fig. 1B,C). By adulthood, testicular ER $\alpha$ mRNA signals were exclusively confined to the Leydig cells (Fig. 1D).

Like ER $\alpha$ mRNA expression, initial signals of ER $\beta$ mRNA in the primordial gonad appeared by fetal day 14 and were diffusely distributed. By fetal day 17, intense signals were localized to the cells found within and along the basal lining of the seminiferous tubules, identified as gonocytes and precursor Sertoli cells respectively (Fig. 1E). The interstitial cells during the prenatal period 
possessed only weak signals of $\mathrm{ER} \beta \mathrm{mRNA}$, in contrast to the intense signals located within the seminiferous tubules (Fig. 1E). The signal intensity of ER $\beta$ mRNA in the germ and Sertoli cells gradually decreased with development, and the signals were barely detectable in adulthood. Furthermore, the signals in Leydig cells progressively weakened with age, becoming undetectable after birth. However, in adulthood, distinct signals of $\mathrm{ER} \beta \mathrm{mRNA}$ were localized to the walls of arteries located between seminiferous tubules (Fig. 1F).

\section{Reproductive tract}

By fetal day 17, distinct and intense signals of ER $\alpha$ mRNA appeared in the epithelium of the mesonephric tubules, which gives rise to the efferent ducts and, presumably, the initial segment of the epididymis (Fig. 2A). In contrast, $\mathrm{ER} \alpha \mathrm{mRNA}$ expression in the mesonephric ducts, from which the epididymis and vas deferens arise, were limited to the outermost cell layer of the ducts at the onset of their appearance (fetal day 14) (Fig. 2D). ER $\alpha$ mRNA expression in the primordial epididymis and vas deferens gradually spread inwards towards the centrally located epithelium during the perinatal period (Fig. 2E-F). The epithelia in the mesonephric ducts lacked signals of ER $\alpha$ mRNA (Fig. $2 \mathrm{D}, \mathrm{F})$. In the adult rat, the expression pattern and intensity of ER $\alpha$ mRNA in the efferent duct and initial segment of the epididymis remained unchanged (Fig. 2B,C), whereas the stroma and epithelia in the rest of the epididymis (Fig. 2G) and smooth muscle layer in the vas deferens (Fig. $2 \mathrm{H})$ expressed weak to moderate signals for ER $\alpha$ mRNA.

ER $\beta$ mRNA signals in the mesonephric tubules ducts were weak during the perinatal period and were localized to the stroma but were not in the epithelia. This expression pattern remained unchanged after the differentiation of these structures into the efferent duct, initial segment of the epididymis, epididymis and vas deferens. In the adult rat, ER $\beta$ mRNA expression was diffusely localized to the stroma and muscle layer of the efferent ducts, epididymis (Fig. 3B,C) and vas deferens.

\section{Sex accessory glands and urethra}

By fetal day 17, distinct and intense signals of ER $\alpha$ mRNA were detectable in the subepithelial stroma of the glandular structures adjacent to the developing bladder (Fig. 2I) and of the urethra (Fig. 2K) respectively. The glandular structures were identified as the primordia of the prostate and seminal vesicular glands, which develop precociously. Following parturition and differentiation, $\mathrm{ER} \alpha \mathrm{mRNA}$ signals persisted in the stroma and, in some glands, they also extended to the smooth muscle layers of the excretory ducts, but were never localized to the glandular and ductal epithelium. This expression pattern remained unchanged in adulthood. In contrast, the initial signals of $\operatorname{ER} \beta$ mRNA, recognizable by postnatal day 8 , in the sex accessory glands were localized diffusely in the stroma and epithelia of the glands. Similar to ER $\alpha$ mRNA, ER $\beta$ mRNA signals in the urethra were localized to the muscle layer and became detectable by fetal day 17 (Fig. 3A). Thereafter, they were observed mainly in the epithelial cells of the seminal vesicles (Fig. 3D), prostate (Fig. 3E), and urethra, bulbo-urethral (Fig. $3 \mathrm{~F}$ ) and urethral glands (Fig. $3 \mathrm{G}$ ).

A summary of the differential expression patterns of ER $\alpha$ and $\operatorname{ER} \beta$ mRNAs in the cells of the male reproductive organ of the rat as revealed by in situ hybridization is shown in Table 1 and Fig. 4.

\section{DISCUSSION}

\section{ER mRNA expression in the testis}

In rodents, spermatogenesis commences soon after the appearance of the seminiferous tubules, around fetal day 15 (Rugh 1988). The undifferentiated gonocytes proliferate and increase in cell size up to fetal days 16-17, and thereafter remain in a quiescent state until after birth (Rugh 1988). The intense prenatal expression of ER $\beta$ mRNA in the undifferentiated gonocytes and Sertoli cells, which coincides with the onset of their proliferation, suggests that estrogen may play a role in regulating early germ cell production via ER $\beta$. In support of this idea is the finding that estrogen stimulates proliferation of gonocytes isolated from the testes of postnatal day 3 rats (Li et al. 1997). Similarly, the onset of ER $\alpha$ mRNA expression in interstitial cells of the testis correlates with the beginning of androgen production and the presence of aromatase in these cells (Ojeda \& Urbanski 1988). Thus, estrogen may also be involved in regulating steroidogenesis during perinatal development via $\mathrm{ER} \alpha$. Furthermore, the demonstration of aromatase activity and ER mRNAs in both the spermatozoa and the Leydig cells (Levallet et al. 1998) indicates the existence of local estrogen autocrine systems in the testis. Finally, the findings that intratesticular administration of estrogen inhibits testosterone production by Leydig cells and that the initial response of Leydig cells to luteal hormone treatment in the adult rat results in increased secretion of testosterone, followed by a significant 


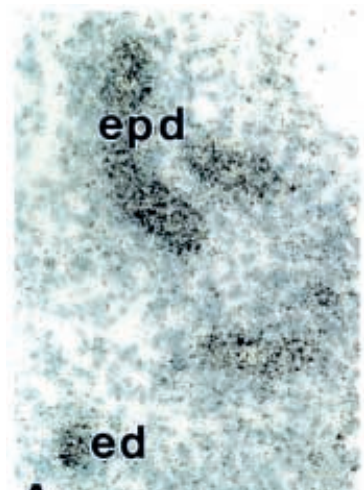

A.
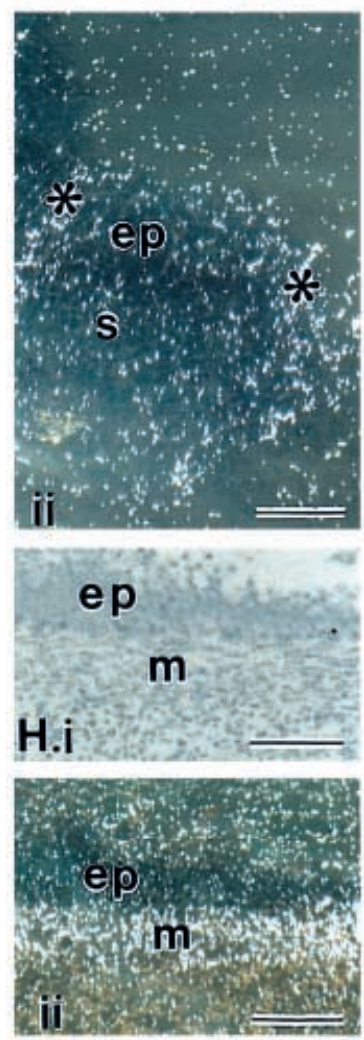
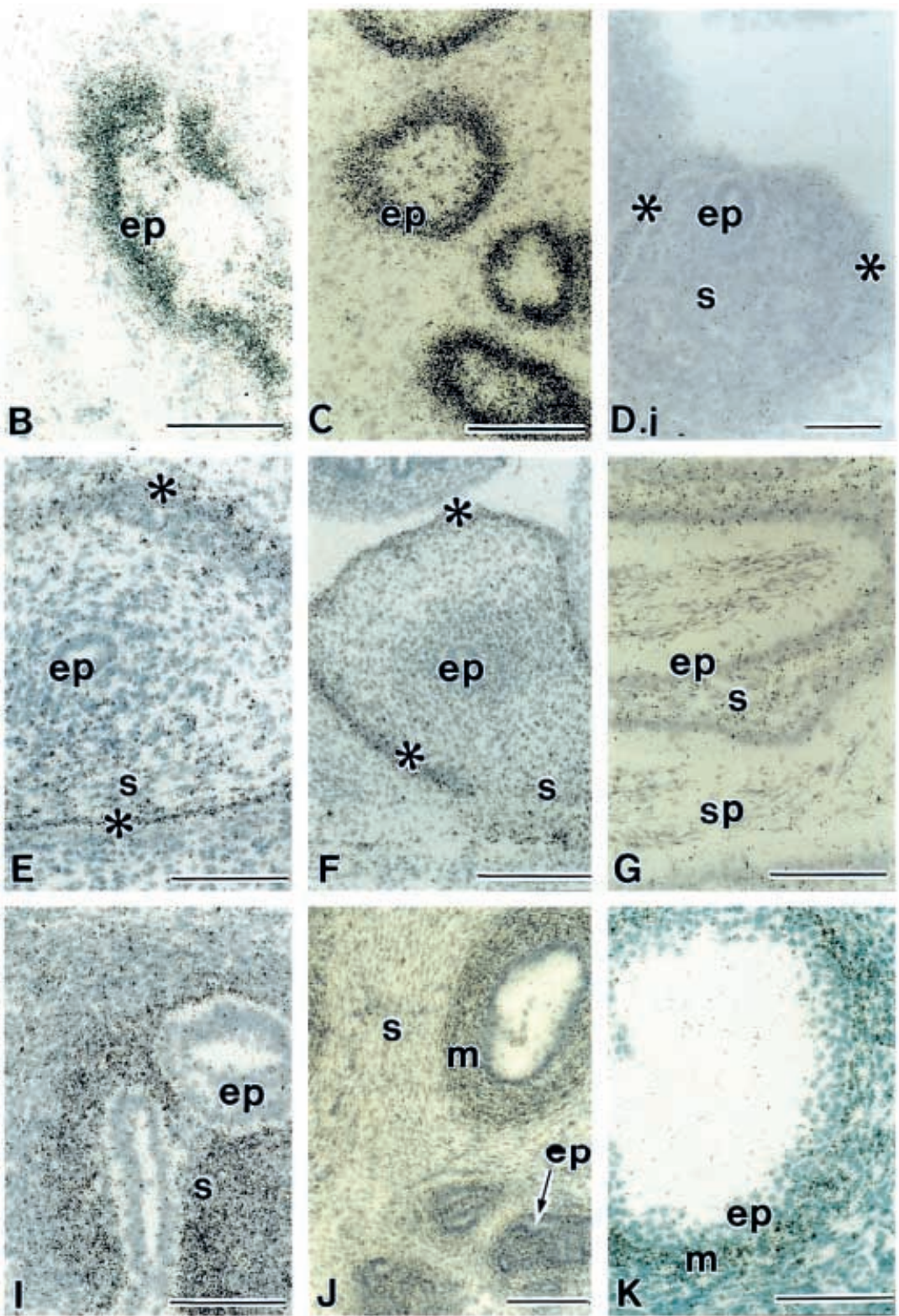
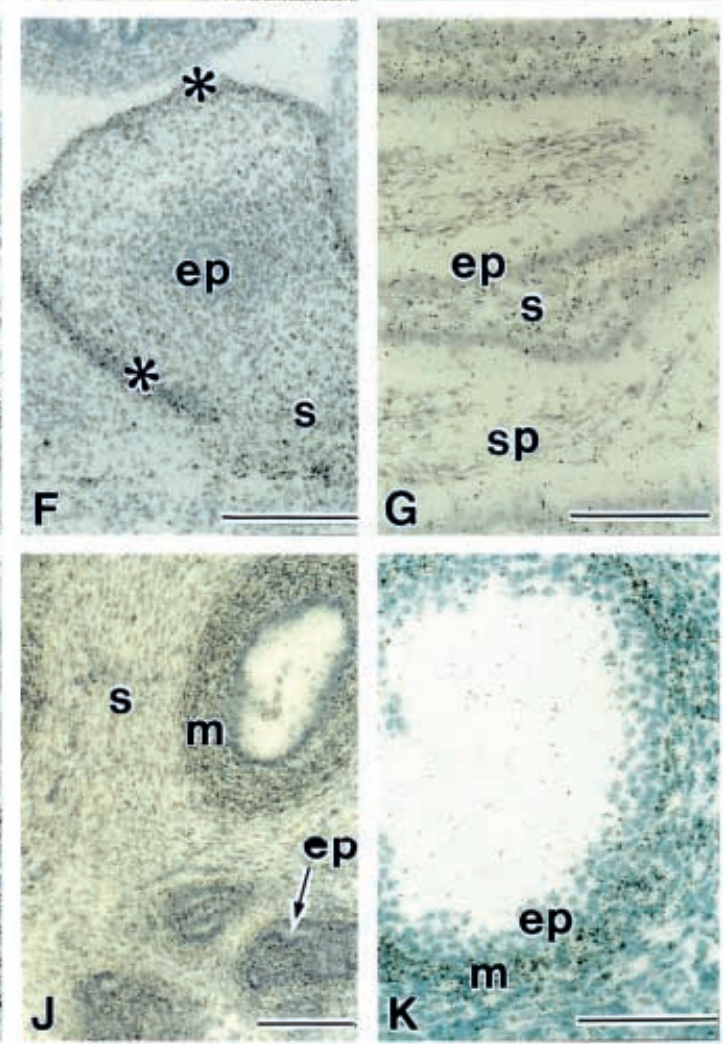

FIGURE 2. Cellular localization of ER $\alpha$ mRNA in the reproductive tract and sex accessory glands of the rat during development and adulthood. (A) Intense ER $\alpha$ mRNA signals are localized to the epithelia in primordial efferent duct (ed) and initial segment of the epididymis (epd) at fetal day 17. (B-C) In the adult, signals of ER $\alpha$ mRNA are confined to the epithelia (ep) of the efferent duct (B, short straight part of the efferent duct) and initial segment of the epididymis, located at the borders with the efferent duct (C, epithelium type - columnar). (D) Detectable signals of ER $\alpha$ mRNA are first seen at fetal day 14 in the outermost cellular layer $(*)$ of the primordial epididymis and vas deferens, as revealed by the bright (i) and dark-field (ii) images (ep, epithelia; s, stroma). (E, F) At fetal day 17, ER $\alpha$ mRNA signal intensity increases significantly in the serosa (*) of the primordial epididymis (E) and vas deferens $(\mathrm{F})$ and significant signals spread to the stroma (s) (ep, epithelia). (G, H) In the adult, ER $\alpha$ mRNA signals are localized to the epithelia (ep) and stroma (s) of the epididymis $(\mathrm{G})$, and to the smooth muscle cells $(\mathrm{m})$ of the vas deferens (sp, spermatozoa) (H.i,ii). (I) In the sex accessory glands, the first signals of ER $\alpha$ mRNA are observed at fetal day 17 in the stroma (s), not in the epithelium (ep). (J) At postnatal day 24, strong signals of ER $\alpha$ mRNA are detected in the lamina propria (lp) and muscle layer $(\mathrm{m})$ of the sex accessory glands. (K) Signals of ER $\alpha$ mRNA in the primordial urethra are limited to the smooth muscle $(\mathrm{m}$ ) (fetal day 17). Bar $=100 \mu \mathrm{m}$ (A, C-E, H, J, K), $200 \mu \mathrm{m}(\mathrm{B}, \mathrm{F}, \mathrm{G}, \mathrm{I})$. 

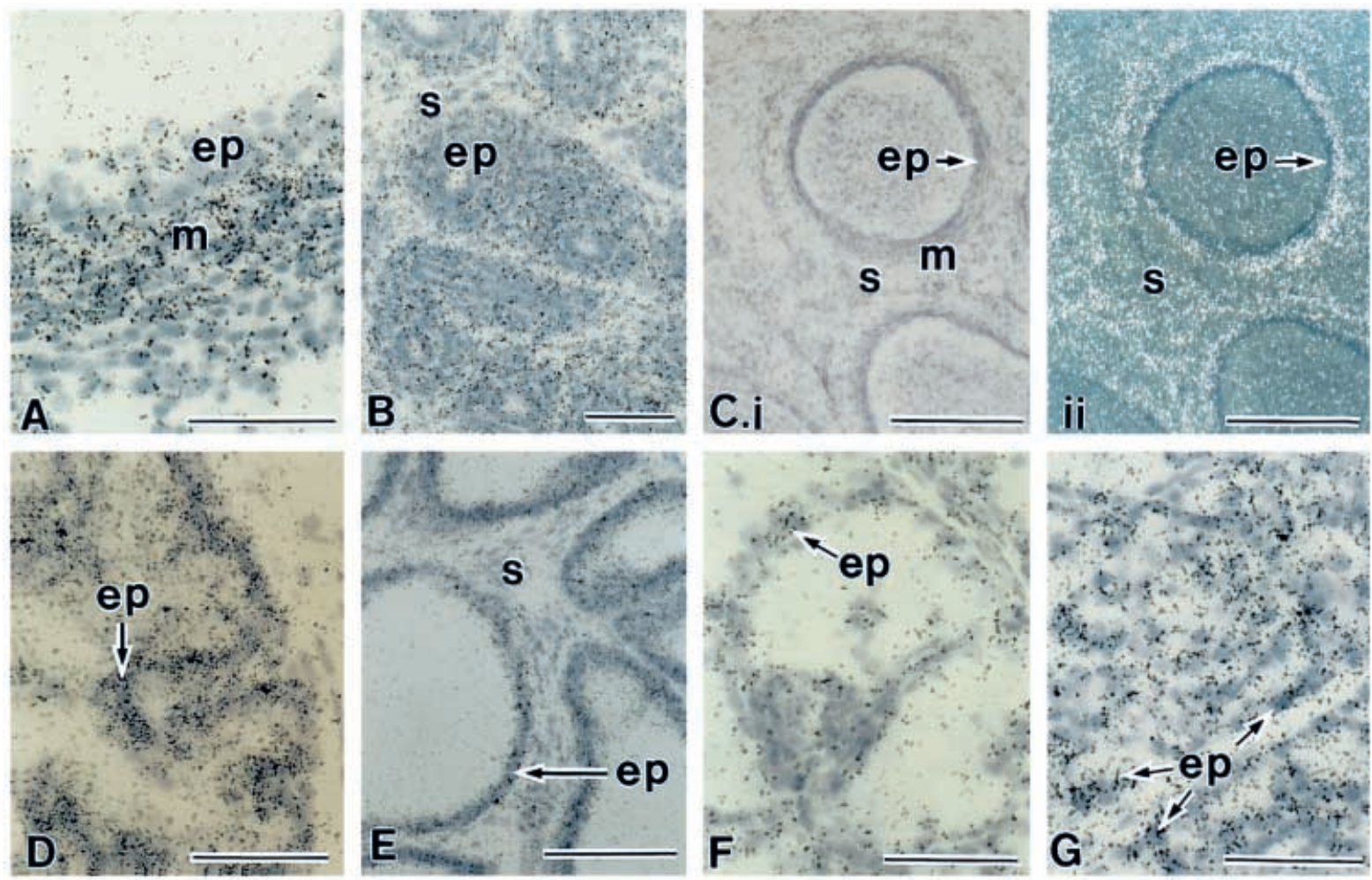

FIGURE 3. Cellular localization of ER $\beta$ mRNA in the reproductive tract and sex accessory glands of the rat during development and adulthood. (A) ER $\beta$ mRNA signals in the reproductive tract are limited to the smooth muscle cells $(\mathrm{m})$ of the urethra at fetal day 17 (ep, epithelium). (B,C) In the adult, ER $\beta$ mRNA signals in the cauda epididymis (B) are diffusely expressed, whereas in the caput epididymis (C.i,ii) fairly distinct signals aggregate in the muscle layer (m) and stroma (s), but not in the epithelium (ep). (D,E) The epithelia (ep) of the seminal vesicles (D) and prostate glands (E) show intense signals of ER $\beta$ mRNA in the adult. (F) Weak to moderate signals of ER $\beta$ mRNA are expressed in the epithelia (ep) of bulbo-urethral glands of the adult. (G) The most intense signals of ER $\beta$ mRNA in the reproductive tract and glands of the adult male rat are localized to the epithelia (ep) of the urethral glands. Bar=100 $\mu \mathrm{m}(\mathrm{B}), 200 \mu \mathrm{m}(\mathrm{C}-\mathrm{G}), 210 \mu \mathrm{m}(\mathrm{A})$.

increase in estrogen production, confirms the above conclusion (Saez 1994). It is noteworthy that the differential expression pattern of ER subtypes in the testis is analogous to that seen in the ovary: $\operatorname{ER} \beta$ is localized to the granulosa cells (oocyte-nurturing cells, i.e. Sertoli cells), whereas ER $\alpha$ is expressed in the theca/interstitial complex (steroid-producing cells, i.e. Leydig cells) (Mowa \& Iwanaga 2000).

The differential cellular expression of $\mathrm{ER} \alpha$ and $\mathrm{ER} \beta \mathrm{mRNA}$ in the testis, as revealed in this study, is generally consistent with previous immunohistochemical and in situ hybridization studies using rodents, with minor differences (Saunders et al. 1997, 1998, Fisher et al. 1997). In accordance with the results of the present study, the expression of ER $\beta$ mRNA was demonstrated in the total RNA of a 14-day postconception mouse testis by ribonuclease protection assay (RPA) (Jefferson et al. 2000). The signal intensities of ER $\beta$ mRNA and protein, and $\mathrm{ER} \alpha \mathrm{mRNA}$, significantly decreased after postnatal days 5 and 19 respectively (Jefferson et al. 2000). In their earlier study, Saunders and colleagues (1997) failed to detect any significant immunoreactivity of $\operatorname{ER} \beta$ in the adult testis, while a different research group (Fisher et al. 1998) localized ER $\alpha$ largely in the interstitial cells from the fetal period through to adulthood in rats, in agreement with our observation. Furthermore, similar to the present data, no ER $\beta$ immunoreactivity was found in the germ cells of adult testis by Pelletier et al. (2000). On the contrary, some immunohistochemical and in situ hybridization studies have reported expression of ER $\beta$ protein and mRNA in the differentiated germ cells of the adult testis (Saunders et al. 1998, van Pelt et al. 1999) and $\mathrm{ER} \alpha$ protein in the Sertoli cells, round spermatocytes and developing spermatids of adult rats (Pelletier et al. 2000). Although the cause of this 
TABLE 1. Chronological order of appearance and changing patterns of $\mathrm{ER} \alpha$ and $\mathrm{ER} \beta \mathrm{mRNA}$ expression in the reproductive organs of the male rat

\begin{tabular}{|c|c|c|c|}
\hline \multirow{3}{*}{ Tissue } & \multirow[b]{2}{*}{ Age (days) } & \multicolumn{2}{|c|}{ ER expression* } \\
\hline & & \multirow[t]{2}{*}{$\mathrm{ER} \alpha$} & \multirow[t]{2}{*}{$\mathrm{ER} \beta$} \\
\hline & & & \\
\hline Testis & $14 \mathrm{f}$ & & \\
\hline Germ cells & $19 \mathrm{f}, 7 \mathrm{p}$, adult & $+/-,+,-$ &,,$++++++/-$ \\
\hline Sertoli cells & $19 f$, adult &,$- \sim$ &,$++1-$ \\
\hline Leydig cells & $17 \mathrm{f}, 7 \mathrm{p}$, adult &,,++++++ &,$++/-, \sim$ \\
\hline \multicolumn{4}{|l|}{ Efferent duct } \\
\hline Epithelium & $17 \mathrm{f}, \sim$ &,$+++ \sim$ &,$- \sim$ \\
\hline Stroma & $17 f$, adult &,$++/-$ & $+1-,-$ \\
\hline \multicolumn{4}{|l|}{ Epididymis } \\
\hline Epithelium & 14f, adult &,-+ & - \\
\hline Stroma & $14 \mathrm{f}, 19 \mathrm{f}$, adult &,,++++++ & $+/-,+/-,+$ \\
\hline \multicolumn{4}{|l|}{ Vas deferens } \\
\hline Epithelium & $14 \mathrm{f}, \sim$ & - & - \\
\hline Stroma & $14 \mathrm{f}, 19 \mathrm{f}$, adult &,,+++++++ & $+/-,+/-,+$ \\
\hline \multicolumn{4}{|c|}{ Sex accessory glands } \\
\hline Epithelium & $17 \mathrm{f}, 8 \mathrm{p}$, adult &,$- \sim$ &,,-++++ \\
\hline Stroma & $17 \mathrm{f}, 8 \mathrm{p}$, adult & $+++, 11, \sim$ &,$-+/-,-$ \\
\hline \multicolumn{4}{|c|}{$\begin{array}{l}\mathrm{f}=\mathrm{fetal} ; \mathrm{p}=\text { postnatal. } \\
\text { *ER signal strength: }+ \text {, weak; }++ \text {, moderate; }+++ \text {, strong; }+/- \text {, inconsistent signals; } \\
\sim \text {, signal unchanged thereafter. } \\
\text { The column under Age indicates when significant ER mRNA signals become detectable; } \\
\text { the middle and last figures (where applicable) indicate the age at which ER mRNA signal } \\
\text { strength sharply increases and plateaus respectively. }\end{array}$} \\
\hline
\end{tabular}

discrepancy is unclear, the idea that $\operatorname{ER} \beta$ plays no role in gametogenesis during adulthood is supported by analyses of ER $\beta$-knockout mice, which are fertile and show no apparent morphological and functional abnormalities in the testis (Couse \& Korach 1999).

\section{ER mRNA expression in the efferent duct, epididymis and vas deferens}

The role of estrogen and the expression of its receptors in the efferent duct have been elaborately investigated in the past largely by immunohistochemistry, steroid autoradiography and RT-PCR, notably by the laboratories of Hess (Cooke et al. 1991, Hess et al. 1997a,b, 2000, Hess 2000, Lee et al. 2000). However, data on the cellular distribution of ER mRNA in the rat from efferent duct to vas deferens, particularly in development, are lacking. This study is the first to describe the cellular expression of ER mRNA in the efferent duct, epididymis and vas deferens during development, and extends our knowledge of ER mRNA expression in the adult rat.

Clulow et al. (1994) have shown that the efferent duct concentrates spermatozoa by re-absorbing more than $90 \%$ of the fluid released from the testis, a process essential for sperm maturation and storage and, subsequently, crucial for optimal male fertility. Among the factors involved in this process are solutes such as $\mathrm{Na}^{+}$and $\mathrm{Cl}^{-}$in luminal fluids, and the water channel protein, aquaporin-1 (AQP-1), expressed in the epithelium (Clulow et al. 1994, Fisher et al. 1998). In the efferent ducts of the adult, estrogen is thought to regulate fluid re-absorption, in part, by modulating the expression of AQP-1 (Fisher et al. 1998). Thus, loss of ERa function in the ER $\alpha$-knockout mice leads to low sperm count and marked structural alterations such as decrease in epithelia height, number of cilia, height of microvillus brush border and density of lysosome and endocytotic organelles (Hess et al. 2000). Consequently, these changes interfere with the resorptive functions of the efferent duct (Couse \& Korach 1999, Hess 2000, Lee et al. 2000). It is interesting to note that AQP-1 signals, like those of $\mathrm{ER} \alpha$ reported here, are intensely expressed in the efferent duct from the prenatal period through adulthood (Fisher et al. 1998). Furthermore, in perinatal rats treated with diethylstilbesterol, AQP-1 immunoreactivity was abolished by postnatal day 18 , accompanied by severe dilatation of efferent ducts, suggesting impaired function of fluid re-absorption (Fisher et al. 1999). These 

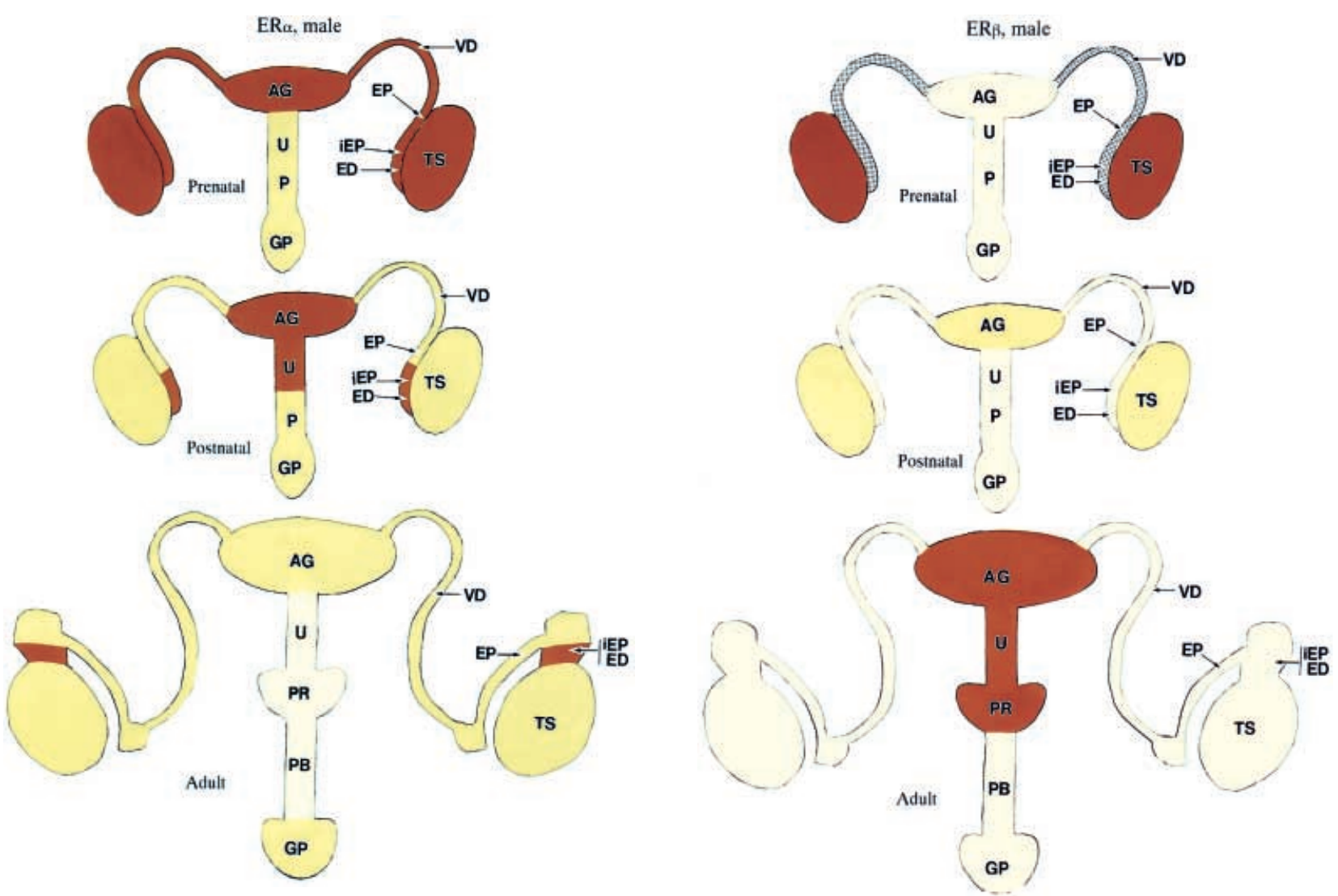

FIGURE 4. Schematic representation of the overall distribution and signal intensity of ER $\alpha$ and ER $\beta$ mRNAs in the reproductive organs of the male rat during the prenatal and postnatal periods and in adulthood. Signal intensity is represented by: red, intense signals; bright yellow, moderate signals; light yellow, weak signals; stipple, insignificant signals. TS, testis; ED, efferent duct; iEP, initial segment of epididymis; EP, main epididymis; VD, vas deferens, $\mathrm{AG}$, accessory gland; $\mathrm{U}$, urethral gland; P, penis; PR, penis root; PB, penis body; GP, glans penis.

observations, taken together with the present findings, indicate that provision for fluid reabsorption is established long before the onset of sexual maturation. Thus, estrogen may play a role in both the development and function of the efferent duct during the perinatal period. ER $\alpha$ and $\operatorname{ER} \beta$ have been localized in the developing and mature epididymis and ductus deferens of rodents by previous studies using immunohistochemistry, RTPCR, RPA and steroid autoradiography, but not by in situ hybridization (Cooke et al. 1991, Greco et al. 1992, Hess et al. 1997a, Jefferson et al. 2000). The data of these studies are largely consistent with the present data. Studies by steroid autoradiography, which detects cells expressing both ER subtypes, demonstrated that fetal mesenchyme accumulates labeled estrogen (Cooke et al. 1991). Following their differentiation into stroma, fibroblasts and smooth muscle cells, the signal pattern changed, with stroma and fibroblasts retaining the signals until adulthood, whereas the smooth muscle cells had weak or no signals (Cooke et al. 1991). The signal pattern of fetal mesenchyme described above may correspond to the pronounced expression of ER $\alpha$ mRNA in the primordial epididymis and vas deferens, as observed in the present study, whereas the stromal signals seen in the adult may correspond to the expression of both ER mRNA subtypes in the stroma of the same structures.

$\mathrm{ER} \alpha \mathrm{mRNA}$ expression in the epididymis, originally detected in the outermost cell layer of the duct and later in the epithelia and stroma, suggests roles for estrogen in its development and function. The epididymis is a negligible site of sperm concentration in comparison to the efferent duct (Clulow et al. 1994). It is, instead, a site of sperm storage and maturity characterized by accumulation of high concentrations of organic compounds (Clulow et al. 1994). Hence, the presence of $\mathrm{ER} \alpha$ mRNA signals in the epididymis implies that 
estrogen modulates secretion of factors that promote the maturity and viability of spermatozoa. This conclusion is consistent with data for $\mathrm{ER} \alpha$-knockout mice, whose spermatozoa lack motility and the ability to fertilize oocytes in vitro (Couse \& Korach 1999). Like the epididymis, the initial signals of ER $\alpha$ expression in the vas deferens were localized to the outermost cell layer of the duct. The similarity in the expression patterns between the two ducts may reflect their common ontogenic origin (Rugh 1988). In the adult, the presence of $\mathrm{ER} \alpha \mathrm{mRNA}$ in the muscle layer of the vas deferens, in accordance with previous immunohistochemical studies, confirms an earlier proposal that estrogen may regulate contraction of the vas deferens, essential for transporting the spermatozoa. Interestingly, our previous study revealed significant expression of $\mathrm{ER} \alpha \mathrm{mRNA}$ in the muscle coat of the rat oviduct (Mowa \& Iwanaga 2000), and physiological studies have demonstrated that estrogen administration accelerates transportation of the oocyte in the oviduct (Harper 1988), possibly via ER expressed in the oviductal muscle coat.

\section{ER mRNA expression in the sex accessory glands}

Prins et al. (1997, 1998) have eloquently described in detail the pattern of $\mathrm{ER} \alpha$ and $\mathrm{ER} \beta$ mRNAs/ proteins expression in the prostate gland of the rat from birth to adulthood using immunohistochemistry, in situ hybridization and RT-PCR. They, with others, have demonstrated that ER $\beta$ mRNA signals are intense in the epithelium of the prostate gland and that this intensity increases with development and age, in contrast to the situation in the stroma where intensity decreases with age (Prins et al. 1998, Pelletier et al. 2000). The present study confirms these earlier findings and provides new data on the expression of ER $\alpha$ and $\operatorname{ER} \beta$ mRNAs in the primordia of the sex accessory glands, in general, during the prenatal period. However, our data are inconsistent with the findings of Jefferson et al. (2000) who, using RPA, were only able to detect low and varying levels of ER $\beta$ mRNA in the seminal vesicle and prostate glands of CD-1 mice between postnatal days 1-26. The cause of the discrepancy is unclear. It is, however, interesting to note that a different study group, which also used mice, found signals in the prostate and bulbourethral glands during development (Cooke et al. 1991).

The seminal vesicles and prostate glands in rodents develop into large structures by fetal day 18 and increase significantly in size after birth (Rugh 1988). The detection of intense $\mathrm{ER} \alpha$ signals in the

www.endocrinology.org developing accessory glands suggests the involvement of ER $\alpha$ in the growth of these glands. The presence of ER $\beta$ in the epithelia of the glands after the neonatal period suggests that the regulatory role of estrogen in their growth and/or secretion is mediated by ER $\beta$. Indeed, ER $\beta$-knockout mice show growth impairment in the secretory portion of the accessory glands, manifested as hyperproliferation which is absent in ER $\alpha$-deficient mice (Gustafsson 1999). On the other hand, ER $\alpha$ expression in the stroma and later in the excretory ducts of these glands indicates that estrogen may modulate the development of these structures and, following maturation, transportation of their secretory products via $\mathrm{ER} \alpha$.

Pheromones, which are vital for social and sexual intercourse, are released via the urine in adult rats (Sasaki et al. 1999). Other than the preputial glands, the source of pheromones in the reproductive organs is unclear. Since pheromone production is partly influenced by estrogen as well as by testosterone, the intense expression of $\operatorname{ER} \beta$ in the secretory portion of the urethral gland indicates that this gland may be another source of pheromones.

Our findings of ER $\alpha$ and ER $\beta$ mRNA expression in the male reproductive tract confirm observations of earlier steroid autoradiographic, in situ hybridization, RT-PCR and immunohistochemical studies, which demonstrated expression of ER in the efferent ducts, epididymis, sex accessory glands and urethra (Fisher et al. 1997, Hess et al. 1997a, Prins \& Birch 1997, Saunders et al. 1997, Prins et al. 1998, Pelletier et al. 2000). Furthermore, this study provides the first report on the onset and expression pattern of ER mRNA subtypes in the developing efferent duct, epididymis, some accessory glands and urethra.

\section{REFERENCES}

Byskov AG \& Hoyer PE 1988 Embryology of mammalian gonads and ducts. In The Physiology of Reproduction, vol 2, pp 265-302. Eds E Knobil \& JD Neill. New York: Raven Press, Ltd.

Carreau S, Genissel C, Bilinska B \& Levallet J 1999 Sources of oestrogen in the testis and reproductive tract of the male. International Fournal of Andrology 22 211-223.

Clulow J, Jones RC \& Hansen LA 1994 Micropuncture and cannulation studies of fluid composition and transport in the ductuli efferentes testis of the rat: comparisons with the homologous metanephric proximal tubule. Experimental Physiology 79 915-928.

Cooke PS, Young P, Hess RA \& Cunha GR 1991 Estrogen receptor expression in developing epididymis, efferent ductules, and other male reproductive organs. Endocrinology 128 2874-2879.

Couse JF \& Korach KS 1999 Estrogen receptor null mice: what have we learned and where will they lead us? Endocrine Reviews 20 358-417.

Fournal of Molecular Endocrinology (2001) 26, 165-174

Downloaded from Bioscientifica.com at 04/26/2023 10:06:59AM via free access 
Fisher JS, Millar MR, Majdic G, Saunders PT, Fraser HM \& Sharpe RM 1997 Immunolocalization of oestrogen receptor-alpha within the testis and excurrent ducts of the rat and marmoset monkey from perinatal life to adulthood. Fournal of Endocrinology 153 485-495.

Fisher JS, Turner KJ, Fraser HM, Saunders PT, Brown D \& Sharpe RM 1998 Immunoexpression of aquaporin-1 in the efferent ducts of the rat and marmoset monkey during development, its modulation by estrogens, and its possible role in fluid resorption. Endocrinology 139 3935-3945.

Fisher JS, Turner KJ, Brown D \& Sharpe RM 1999 Effect of neonatal exposure to estrogenic compounds on development of the excurrent ducts of the rat testis through puberty to adulthood. Environmental Health and Perspective 107 397-405.

Freeman ME 1988 The ovarian cycle of the rat. In The Physiology of Reproduction, vol 2, pp 1893-1928. Eds E Knobil \& JD Neill. New York: Raven Press, Ltd.

Galand P, Leroy F \& Chretien J 1971 Effect of oestradiol on cell proliferation and histological changes in the uterus and vagina of mice. Fournal of Endocrinology 49 243-252.

Greco TL, Furlow JD, Duello TM \& Gorski J 1992 Immunodetection of estrogen receptors in fetal and neonatal male mouse reproductive tracts. Endocrinology 130 421-429.

Gustafsson JA 1999 A new dimension in estrogen mechanism of action. Fournal of Endocrinology 163 379-383.

Harper MJK 1988 Gamete and zygote transport. In The Physiology of Reproduction, vol 2, pp 103-134. Eds E Knobil \& JD Neill. New York: Raven Press, Ltd.

Hess RA 2000 Oestrogen in fluid transport and reabsorption in efferent ducts of the male reproductive tract. Review of Reproduction 5 84-92.

Hess RA, Gist DH, Bunick D, Lubahn DB, Farrell A, Bahr J, Cooke PS \& Greene GL $1997 a$ Estrogen receptor $(\alpha$ and $\beta$ ) expression in the excurrent ducts of the adult male rat reproductive tract. Fournal of Andrology 18 602-611.

Hess RA, Bunick D, Lee KH, Bahr J, Taylor JA, Korach KS \& Lubahn DB $1997 b$ A role for oestrogens in the male reproductive system. Nature 390 509-512.

Hess RA, Bunick D, Lubahn DB, Zhou Q \& Bouma J 2000 Morphologic changes in efferent ductules and epididymis in estrogen receptor-alpha knockout mice. Fournal of Andrology 21 107-121.

Janulis L, Bahr JM, Hess RA, Janssen S, Osawa Y \& Bunick D 1998 Rat testicular germ cells and epididymal sperm contain active P450 aromatase. Fournal of Andrology 19 $65-71$.

Jefferson WN, Couse JF, Banks EP, Korach KS \& Newbold RR 2000 Expression of estrogen receptor $\beta$ is developmentally regulated in reproductive tissues of male and female mice. Biology of Reproduction 62 310-317.

Koike S, Sakai M \& Muramatsu M 1987 Molecular cloning and characterization of rat estrogen receptor cDNA. Nucleic Acids Research 15 2499-2513.

Kuiper GGJM, Enmark E, Pelto-Hnikko M, Nilsson S \& Gustafsson JA 1996 Cloning of a novel estrogen receptor expressed in the rat prostate and ovary. PNAS 93 $5925-5930$

Lee KH, Hess RA, Bahr JM, Lubahn DB, Taylor J \& Bunick D 2000 Estrogen receptor alpha has a functional role in the mouse rete testis and efferent ductules. Biology of Reproduction 63 1873-1880.

Levallet J, Bilinska B, Mittre H, Genissel C, Fresnel J \& Carreau S 1998 Expression and immunolocalization of functional cytochrome $\mathrm{P} 450$ aromatase in mature rat testicular cells. Biology of Reproduction 58 919-926.

Li H, Papadopoulos V, Vidic B, Dym M \& Cluty M 1997 Regulation of rat testis gonocyte proliferation by platelet derived growth factor and estradiol: identification of signaling mechanisms involved. Endocrinology 138 1289-1298.

Meistrich ML, Hughes TJ \& Bruce WR 1975 Alteration of epididymal sperm transport and maturation in mice of oestrogen and testosterone. Nature 258 145-147.

Mowa CN \& Iwanaga T 2000 Differential distribution of oestrogen receptor- $\alpha$ and $-\beta$ mRNAs in the female reproductive organ of rats as revealed by in situ hybridization. Fournal of Endocrinology 165 59-66.

Ojeda SR \& Urbanski HF 1988 Puberty in the rat. In The Physiology of Reproduction, vol 2, pp 1699-1737. Eds E Knobil \& JD Neill. New York: Raven Press, Ltd.

Pelletier G, Labrie C \& Labrie F 2000 Localization of oestrogen receptor $\alpha$, oestrogen receptor $\beta$ and androgen receptors in the rat reproductive organs. Fournal of Endocrinology 165 359-370.

van Pelt AM, de Rooij DG, van der Burg B, van der Saag PT, Gustafsson JA \& Kuiper GG 1999 Ontogeny of estrogen receptor-beta expression in rat testis. Endocrinology $\mathbf{1 4 0}$ 478-483.

Prins GS \& Birch L 1997 Neonatal exposure up-regulates estrogen receptor expression in the developing and adult lobes. Endocrinology 138 1801-1809.

Prins GS, Marmer M, Woodham C, Chang W, Kuiper G, Gustafsson JA \& Birch L 1998 Estrogen receptor- $\beta$ messenger ribonucleic acid ontogeny in the prostate of normal and neonatally estrogenized rats. Endocrinology 139 874-883.

Rugh R 1988 Organogeny. In The Mouse, its Reproduction and Development, pp 285-286. Minneapolis: Burgess Publishing, Co.

vom Saal FS, Timms BG, Montano MM, Palanza P, Thayer KA, Nagel SC, Dhar MD, Ganjam VK, Parmigiani S \& Welshons WV 1980 Prostate enlargement in mice due to fetal exposure to low doses of estradiol or diethylstilbesterol and opposite effects at high doses. PNAS 77 5197-5200.

Saez JM 1994 Leydig cells: endocrine, paracrine, and autocrine regulation. Endocrine Review 15 574-626.

Sasaki K, Okamoto K, Inamura K, Tokumitsu Y \& Kashiwayanagi M 1999 Inositol-1,4,5-trisphosphate accumulation induced by urinary pheromones in female rat vomeronasal epithelium. Brain Research 823 161-168.

Saunders PT 1998 Oestrogen receptor beta (ER beta). Reviews of Reproduction 3 164-171.

Saunders PT, Maguire SM, Gaughan J \& Millar MR 1997 Expression of oestrogen receptor beta (ER beta) in multiple rat tissues visualised by immunohistochemistry. Fournal of Endocrinology 154 R13-R16.

Saunders PT, Fisher JS, Sharpe RM \& Millar MR 1998 Expression of oestrogen receptor beta (ER beta) in multiple cell types, including some germ cells, in the rat testis. Fournal of Endocrinology 156 R13-R17.

Zhai J, Lanclos KD \& Abney TO 1996 Estrogen receptor messenger ribonucleic acid changes during Leydig cell development. Biology of Reproduction 55 782-788.

RECEIVED IN FINAL FORM 9 January 2001 ACCEPTED 17 January 2001 